\title{
Feeding of a larval clinid fish in a microtidal estuary from southern Chile
}

\author{
Alimentación de larvas de un pez clínido en un estuario micromareal del sur de Chile \\ María J. Ochoa-Muñoz ${ }^{1}$, Claudio P. Valenzuela ${ }^{2}$, Silvana Toledo ${ }^{3}$, \\ Claudia A. Bustos ${ }^{1,4}$ and Mauricio F. Landaeta ${ }^{1}$
}

\begin{abstract}
${ }^{1}$ Laboratorio de Ictioplancton (LABITI), Facultad de Ciencias del Mar y de Recursos Naturales, Universidad de Valparaíso, Avenida Borgoño 16344, Reñaca, Viña del Mar, Chile. mauricio.landaeta@uv.cl

${ }^{2}$ Instituto de Ciencias Marinas y Limnológicas, Universidad Austral de Chile, Campus isla Teja, Valdivia, Chile

${ }^{3}$ Escuela de Ciencias, Facultad de Ciencias, Universidad Austral de Chile, Campus isla Teja, Valdivia, Chile

${ }^{4}$ Programa Doctorado en Acuicultura, Universidad Católica del Norte, Larrondo1281, Coquimbo, Chile
\end{abstract}

\begin{abstract}
Resumen.- Es ampliamente reconocida la utilización de estuarios como zonas de crianza para peces e invertebrados, pero el éxito en la explotación de los recursos variará entre las especies residentes del estuario y las oportunistas. Se estudió la distribución y dieta de larvas de Myxodes viridis (Pisces, Clinidae) en 2 localidades del estuario de Bahía Corral (estuarioarriba y estuario-abajo), uno de los estuarios más grandes del sur de Chile, durante la primavera austral de 2009 a 3 profundidades (superficie, picnoclina, profundo) durante la fase llenante y vaciante de 4 ciclos mareales. Las larvas fueron recolectadas principalmente en la estación estuario-abajo durante fase vaciante. La incidencia alimentaria también fue mayor en la fase vaciante; las larvas cambiaron de omnivoría a carnivoría a medida que se desarrollaban, depredando principalmente sobre nauplii y copepoditos calanoideos. Aunque el éxito alimentario fue similar para cada estado de desarrollo en la columna de agua, la dieta de larvas en preflexión y flexión estuvo basada en diferentes ítems presa dentro de los primeros 3-4 m de la columna de agua (superficie y picnoclina) con respecto de aguas más profundas (7-10 m, cerca del fondo). Esto sugiere que la picnoclina pudiera afectar la composición de la dieta de larvas pequeñas de $M$. viridis, pero no el tamaño, número o volumen de presas ingeridas. Además, ya que el forrajeo está basado predominantemente en diferentes estados de desarrollo de copépodos, las larvas que emergen durante vaciante pueden incrementar la advección fuera del estuario hacia zonas costeras cercanas, indicando que esta especie no es un usuario frecuente del estuario durante su desarrollo larval.
\end{abstract}

Palabras clave: Myxodes viridis, ictioplancton, éxito alimentario, Bahía Corral

\begin{abstract}
The utilization of estuaries as nursery zones for fish and invertebrates is widely known, but differences in the success of resource exploitation vary between resident and opportunistic estuarine species. The distribution and diet of larval Myxodes viridis (Pisces, Clinidae) were studied at 2 locations (up-estuary and down-estuary) in the Corral Bay estuary, one of the largest estuaries in southern Chile, during the austral spring 2009 at 3 depths (surface, pycnocline, deep) during the flood and ebb of 4 tidal cycles. Larvae were collected mostly at the down-estuary station during the ebb phase. Feeding incidence was also greater during the ebb phase; larvae changed from omnivory to carnivory as they developed, predating mainly on nauplii and calanoid copepodites. Although the feeding success was similar for each developmental stage along the water column, diet of preflexion and flexion larvae was different in the first 3-4 m depth (surface and pycnocline) in relation to deeper waters (7-10 $\mathrm{m}$ depth, near to the bottom). This suggests that the pycnocline may affect the composition of the diet of small, larval $M$. viridis but not the size, number or volume of ingested prey. Additionally, because foraging is predominantly based on the different life stages of copepods, larvae emerging during the ebb tide may increase the offestuary advection into nearby shelf waters, indicating that this species is not a user of the estuary during its early development.
\end{abstract}

Key words: Myxodes viridis, ichthyoplankton, feeding success, Corral Bay

\section{INTRODUCTION}

Estuaries represent highly dynamic environments, largely utilized as nursery grounds for fishes and crustaceans around the world (Fox et al. 1999, Pardo et al. 2011). The definition of a nursery is based on 4 comparative factors:
(1) density, (2) growth, (3) survival, and (4) movement to adult habitats, i.e., contribution to the adult population (Beck et al. 2003, Able 2005). Larvae of some species recruit in abundance in particular habitats within the 
estuary, accumulate biomass and then migrate to other habitats to breed. Typically, these environments have low predation rates and high food availability (Fox et al. 1999, Islam et al. 2006), but those relationships are likely to vary between resident (with obligate life history stages in the estuary) and facultative users (estuarine opportunists).

In an estuary where physical conditions change over short temporal and spatial scales, it is plausible that the feeding habits of fish larvae may be modified or affected by the vertical structure of the water column. Estuarinedependent species can be affected by a major physical feature of the estuary, the estuarine turbidity maximum (ETM), an area where larval fish retention and feeding increases (North \& Houde 2001, Islam et al. 2006). However, this physical feature does not affect the ecology (feeding and/or growth rates) of non estuarine-dependent coastal fish species (Islam et al. 2006). As established by Able (2005), there is a need for more research concerning biotic factors (e.g., competition, predation, etc.) to enhance our understanding of estuarine dependence, particularly in marine fish species.

Recently, studies of mesopelagic species that utilize fjord environments as spawning and nursery grounds have described changes in food items (Landaeta et al. 2012) and feeding success (i.e., total prey volume per gut, Landaeta et al. 2011) in relation to the surface salinity and vertical stratification, respectively. Additionally, large abundance of larval anchoveta Engraulis ringens has been detected associated to strong water column stratification (Bustos et al. 2008). However, there is little information about the utilization of estuaries by the early life stages of littoral fish species as feeding grounds (Fox et al. 1999, Islam et al. 2006).

The family Clinidae consists of relatively small (less than $300 \mathrm{~mm} \mathrm{SL}$ ) benthic fishes, the majority of which inhabit intertidal and shallow subtidal waters (Nelson 2006). The Clinidae contains 3 tribes (Myxodini, Clinini, and Ophiclinini), 20 genera and 71 species. The Myxodini is characterized by ovuliparous oviparity and the lack of an intromittent organ in males. Five genera are contained in the Myxodini: Myxodes, Heterostichus, Gibbonsia, Ribeiroclinus, and Clinitrachus, from which only Myxodes are found along the west coast of South America (Stepien 1992). In Chile, 3 species are identified, Myxodes viridis Valenciennes, 1836, M. cristatus Valenciennes, 1836, and M. ornatus Stephens and Springer, 1973 (Stephens \& Springer 1973). M. viridis inhabit from
Independencia Bay, Peru to southern Chile, feeding mostly crabs, while juveniles ( $<75 \mathrm{~mm} \mathrm{SL}$ ) primarily ate harpacticoid copepods, amphipods, gastropod snails, and isopods (Stepien 1990). There is no previous information about the feeding habits of either Myxodes viridis larvae or other clinid larvae in Chilean waters.

The Corral Bay estuary $\left(c a ., 40^{\circ} \mathrm{S}\right)$ is a very dynamic estuary, with several interconnected rivers, mainly the Valdivia and Tornagaleones Rivers, which together occupy a hydrographic basin of $13,135 \mathrm{~km}^{2}$. The estuary also has marked saline and thermal stratifications (Pino et al. 1994) and a microtidal regime characterized by a salt wedge or partially mixed circulation, depending on high or low levels of precipitation, respectively (Davila et al. 2002, Pardo et al. 2012). Based on 4 oceanographic cruises carried out in the Corral Bay estuary, we studied the feeding behavior in larval Myxodes viridis. One question was addressed: Is the pycnocline capable of accumulating potential prey and increase the feeding success of larval $M$. viridis? The hypothesis that the pycnocline in an estuary may affect the composition of prey items and feeding success of a larval clinid during the austral spring season was tested.

\section{Materials ANd Methods}

\section{FIELD WORK}

Four cruises were carried out onboard an artisan vessel at 2 locations in the Corral Bay estuary (39 $52^{\prime}$ 'S, $73^{\circ} 25^{\prime} \mathrm{W}$, Fig. 1), one with a greater influence of freshwater (upestuary, Mancera) and the other with a greater influence of shelf waters (down-estuary, San Carlos), during the austral spring 2009 (November-December). During each cruise and at each location, San Carlos and Mancera, the hydrographic conditions (temperature and salinity) were measured throughout the water column using a YSI multiparameter unit, model 556 MPS, and oblique plankton samples were collected with a WP-2 open-close ring net (60 $\mathrm{cm}$ diameter, $300 \mu \mathrm{m}$ mesh size, equipped with a flow meter to estimate the filtered seawater volume) in the mixed layer (1 $\mathrm{m}$ depth), pycnocline (2 to $5 \mathrm{~m}$ depth) and deep layer ( $10 \mathrm{~m}$ depth) by 5-10 min. The plankton net filtered 3.6 to $72.7 \mathrm{~m}^{3}$ (mean \pm standard deviation: $33.7 \pm 15.2 \mathrm{~m}^{3}$ ), being the surface collections shorter in time than the other depth ranges. All plankton samples were fixed with $4 \%$ formaldehyde buffered with sodium borate. Physical and biological sampling was repeated 4 times on each cruise and at each location, 2 during the flood and 2 during the ebb tidal phases of each sampling day. 
Figure 1. Map of the study area, indicating the up-estuary station (Mancera, black triangle) and the down-estuary station (San Carlos, black cross), at the Corral Bay estuary, southern Chile / Mapa del área de estudio, indicando la estación estuario-arriba (Mancera, triángulo negro) y la estación estuario-abajo (San Carlos, cruz negra), en el estuario de la Bahía Corral, sur de Chile

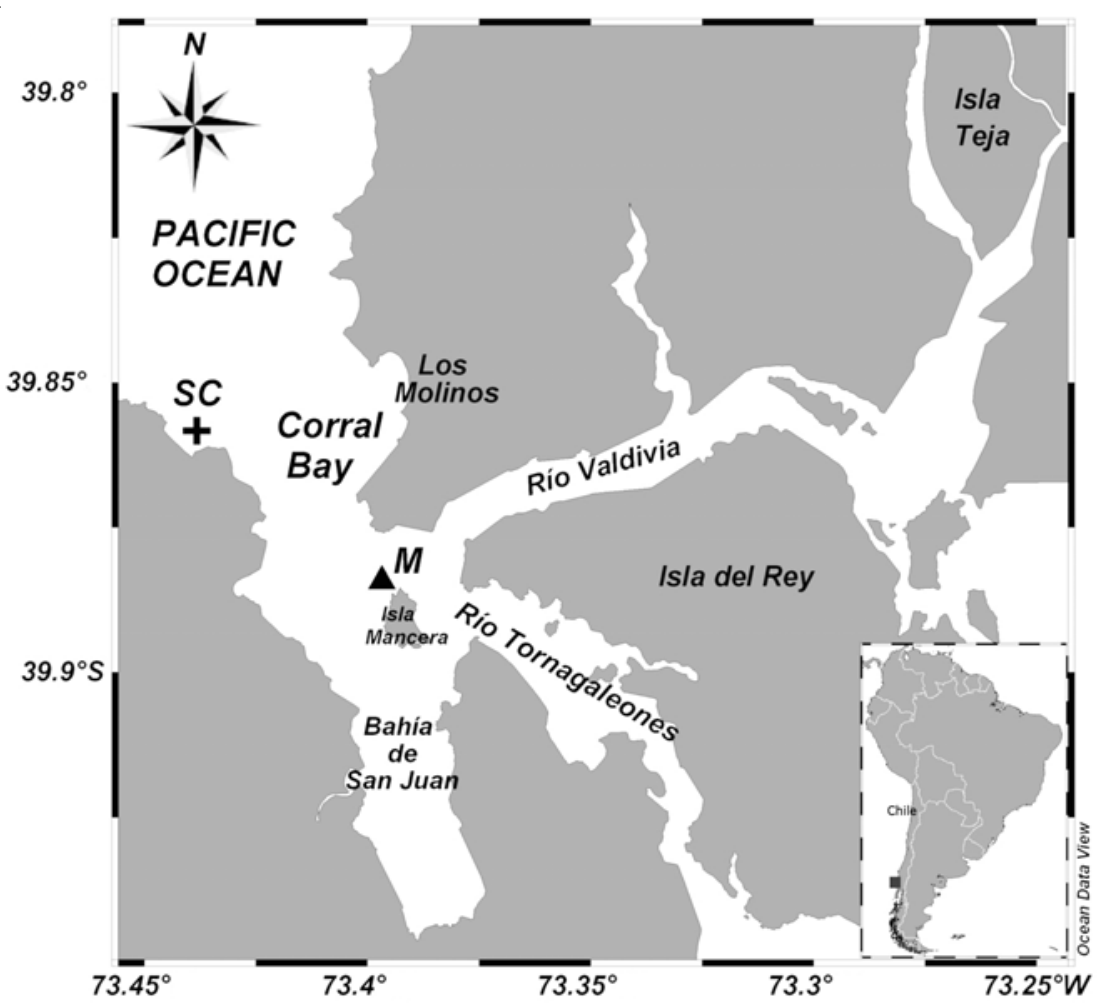

\section{LABORATORY WORK}

In the laboratory, all fish larvae from the plankton samples were separated, counted and identified to the lowest taxonomic level. Larval $M$. viridis were identified by using the series method, which consist of positively identifying the largest available larva, or the smallest juvenile, using known adult characters such as fin meristics, and subsequently linking this specimen with progressively smaller specimens by using general morphological and pigment characters until a developmental series is assembled (Neira et al. 1998). Postlarval M. viridis distinguishes from other Clinidae and Labrisomidae by the number of spines and soft rays in the dorsal fin (D XXIV-XXVI, 6-7), larger preanal length, and persistent punctuate melanophores over the gut throughout the larval development (M.F. Landaeta ${ }^{1}$, unpublished data). Abundance was standardized to individuals per $1000 \mathrm{~m}^{3}$, taking into account the number of larvae captured and volume of the seawater filtered by the net. Body length (BL, notochord length in preflexion larvae; standard length in flexion and postflexion larvae), upper jaw length (UJL, from the tip of the snout to the posterior end of the maxilla) and mouth width (MW, in the ventral view, the width between the posterior edges of the maxillae) of all intact larval M. viridis $(n=291)$ were measured under an Olympus SZ61 stereomicroscope attached to a camera (Motic moticam 2500, resolution 5.0 MPixel) using Motic Image Plus 2.0 software. The gut of each larva was dissected from the body and opened length-wise with fine needles. Prey items were counted and identified to the lowest possible taxon, except for indigestible prey remains such as setae, under a Motic BA310 microscope. The maximum BL and width of each prey item (maximum prey width, MPW) were measured with the microscope and a Motic moticam 2500 camera (resolution 5.0 MPixel) using the Motic Image Plus 2.0 software. The volume of each prey item was estimated using the three-dimensional shape that most closely resembled the item, following Cass-Calay (2003) and Sun \& Liu (2003). The prosome length of copepodite prey was measured because the urosome was often missing.

\footnotetext{
${ }^{1}$ mauricio.landaeta@uv.cl
} 


\section{Data analysis}

All larvae with identifiable prey in their guts were used for the analysis. The relationships between the BL, UJL and MW of the larvae and between the UJL and MPW were determined by linear regression analyses, and comparisons of slopes were performed with a multiple slope test (Zar 1999). Spearman correlations were also calculated.

Larval M. viridis were separated into 3 developmental stages, preflexion, flexion and postflexion larvae to assess changes in the feeding incidence (FI) and prey composition. FI was calculated as a percentage of the total number of larvae with gut contents out of the total number of larvae examined (Sassa \& Kawaguchi 2004). Comparisons of FI among developmental stages (preflexion, flexion and postflexion), sampling strata (surface, pycnocline, deep), station (down-estuary, San Carlos and up-estuary, Mancera), and tidal phase (flood and ebb), were carried out with contingency tables.

The diet was described using the percent frequency of occurrence $(\% F)$ of a diet item in larvae with food in their guts, the percent of the total number $(\% N)$ of diet items that were examined and the percent of volume $(\% \mathrm{~V})$ of each item out of the total volume of prey items. An index of relative importance (IRI) was calculated as follows: IRI $=(\% N+\% V) \times \% F$. To readily allow comparisons among prey items, the IRI was the standardized to \%IRI for each prey item $i$ (Cortés 1997).

To establish the variability in the feeding success of larval $M$. viridis among the vertical strata, 3 measures of feeding success were compared for each developmental stage separately: the number of prey items per gut (PIPG, number), average prey length per gut (PLPG, mm) and total prey volume per gut (TPVG, $\mathrm{mm}^{3}$ ) (Reiss et al. 2002). To avoid the effects of location and tides, only larvae collected during the last cruise at the San Carlos station were utilized for this analysis (Table 2). Because the data were not normally distributed (Shapiro-Wilk tests, $P<$ 0.001 ), the measurements of feeding success were compared using the Kruskal-Wallis ANOVA tests and multiple comparisons of mean ranks.

Finally, to establish the differences in the composition of prey among strata, a multivariate approach was utilized separately for each developmental stage. The prey composition (number of prey) of each larvae was $\log (x+1)$ transformed to enhance the contribution of less abundant prey, and a Bray-Curtis similarity matrix was generated from these data. Similarities between larvae were graphically represented by nonmetric multidimensional scaling (NMDS) ordination. The degree of correspondence between the distances among points was measured by a stress function. A one-way analysis of similarities (ANOSIM), which is analogous to a univariate analysis of variance, was utilized to determine the differences in prey composition among the strata. Pairwise ANOSIM comparisons were made between groups using 10,000 permutations. When differences were detected, a similarity percentage (SIMPER) analysis was carried out to assess which prey taxa were primarily responsible for the observed differences between groups of samples (i.e., larvae).

\section{Results}

\section{Physical settings}

During the 4 tidal cycles studied during austral spring 2009, the hydrographic conditions in the Corral Bay estuary were relatively stable at each sampling station over time (Table 1). Stations located up-estuary (Mancera) were, on average, warmer $\left(\sim 12^{\circ} \mathrm{C}\right)$ and fresher $(21-24)$ than waters located down-estuary (San Carlos) $\left(10-12^{\circ} \mathrm{C}\right.$ and 31-32, respectively) (Table 1). As an example, water column structure of one specific cruise is showed (Fig. 2). The water column structure changed during the tidal phases: during the flood phase, vertical gradients of temperature and salinity were less marked than during the ebb phases at both locations during the last cruise (Fig. 2, Table 1). A halocline occurred at 2-3 m depth at Mancera, but at San Carlos the mixed layer was almost nonexistent, developing a halocline from the surface to $2 \mathrm{~m}$ depth during both ebb and flood phases (Fig. 2).

\section{LARVAL FISH ABUNDANCE}

A total of 95 plankton samples were analyzed. From those, 291 larvae of Myxodes viridis were identified, corresponding to abundances varying from 16.62 to 4217.46 individuals (ind.) per $1000 \mathrm{~m}^{3}$ (mean $\pm \mathrm{sd}$, 444.24 \pm 1014.25 ind. $1000 \mathrm{~m}^{-3}$ ). Larvae were collected at both locations for all samples but almost exclusively during the ebb phase of the tidal cycle (Table 2). Larval abundance was relatively constant at the up-estuary station (Mancera), but it increased through time at San Carlos, reaching the highest values of abundance during mid-December, 2009 (Table 2). 
Table 1. Summary of the physical conditions (temperature and salinity) during the 4 sampling events at 2 stations (Mancera and San Carlos) in the Corral Bay estuary, southern Chile, during the austral spring, 2009 SD = one standar deviation/ Resumen de las condiciones físicas (temperatura y salinidad) durante 4 eventos de muestreo en 2 estaciones (Mancera y San Carlos) en el estuario de la Bahía Corral, sur de Chile, durante la primavera austral de 2009 SD = una desviación estándar

\begin{tabular}{|c|c|c|c|c|c|}
\hline & & \multicolumn{2}{|c|}{ Temperature $\left({ }^{\circ} \mathrm{C}\right)$} & \multicolumn{2}{|c|}{ Salinity } \\
\hline & & Mean \pm SD & Range & Mean \pm SD & Range \\
\hline \multicolumn{6}{|l|}{ 10-11 November } \\
\hline & Mancera & $11.84 \pm 0.79$ & $10.94-12.96$ & $20.99 \pm 13.44$ & $1.47-33.63$ \\
\hline & San Carlos & $11.25 \pm 0.68$ & $10.40-13.10$ & $32.02 \pm 3.16$ & $23.62-34.10$ \\
\hline \multicolumn{6}{|l|}{ 26-27 November } \\
\hline & Mancera & $13.28 \pm 0.67$ & $12.65-15.00$ & $22.44 \pm 12.27$ & $1.82-32.59$ \\
\hline & San Carlos & $12.85 \pm 0.50$ & $12.40-14-52$ & $31.59 \pm 3.30$ & $19.22-33.83$ \\
\hline \multicolumn{6}{|l|}{ 6-7 December } \\
\hline & Mancera & $12.04 \pm 2.10$ & $10.22-15.76$ & $24.65 \pm 11.65$ & $3.63-34.19$ \\
\hline & San Carlos & $10.73 \pm 1.04$ & $9.86-14.09$ & $32.96 \pm 2.51$ & $23.37-34.30$ \\
\hline \multicolumn{6}{|l|}{ 11-12 December } \\
\hline & Mancera & $12.89 \pm 2.36$ & $10.07-16.05$ & $23.73 \pm 10.31$ & $4.62-34.18$ \\
\hline & San Carlos & $10.90 \pm 1.35$ & $9.58-14.99$ & $32.12 \pm 3.77$ & $21.76-34.40$ \\
\hline
\end{tabular}

Table 2. Spatial and temporal variations in the abundance (ind. 1000 $\mathrm{m}^{-3}$ ) of larval Myxodes viridis in the Corral Bay estuary, during spring 2009 / Variaciones espaciales y temporales en la abundancia (ind. $1000 \mathrm{~m}^{-3}$ ) de larvas de Myxodes viridis en el estuario de la Bahía Corral durante primavera de 2009

\begin{tabular}{cccc}
\hline & & Mancera & San Carlos \\
\hline 10-11 November & & & \\
& Flood & 0 & 0 \\
& Ebb & $26.1 \pm 7.3$ & 0 \\
26-27 November & & & \\
& Flood & 0 & 0 \\
& Ebb & $22.2 \pm 7.9$ & $78.4 \pm 86.4$ \\
6-7 December & & & $100.3 \pm 88.4$ \\
& Flood & 0 & $226.9 \pm 55.9$ \\
& Ebb & 37.6 & 0 \\
11-12 December & & & $1814.0 \pm 1724.3$ \\
& Flood & 0 & \\
& Ebb & $56.4 \pm 29.3$ & \\
\hline
\end{tabular}

\section{BODY AND GAPE SIZE RELATIONSHIPS}

Larval M. viridis collected during the austral spring 2009 ranged from 3.14 to $14.46 \mathrm{~mm} \mathrm{BL}$ (mean \pm sd, $6.85 \pm 1.72$ $\mathrm{mm})$. UJL and MW varied between 258.61-1523.53 $\mu \mathrm{m}$ $(600.44 \pm 211.29 \mu \mathrm{m})$ and 137.96-1631.45 $\mu \mathrm{m}$ (512.91 \pm $243.37 \mu \mathrm{m})$, respectively. Linear regressions were significant $(P<0.001)$ and explained 76.2 and $45.1 \%$ of the variability in UJL and MW, respectively (Fig. 3). The jaw length relative to BL varied from 4.95 to $15.96 \%$ (8.69 $\pm 1.62 \%$ ), and the mouth width relative to BL varied from 2.66 to $16.06 \%$ (7.35 $\pm 2.57 \%)$. Additionally, UJL grew faster $\left(107.23 \mu \mathrm{m} \mathrm{UJL} \mathrm{mm} \mathrm{BL}{ }^{-1}\right)$ than MW $(95.02 \mu \mathrm{m}$ UJL mm $\mathrm{BL}^{-1}$ ) relative to the $\mathrm{BL}$ (multiple slope test, $\mathrm{t}=7.32, P<$ 0.001).

\section{FEEDING INCIDENCE}

Only well-preserved larval $M$. viridis ( $n=287$ ) were utilized for the diet analysis. The smallest larva with gut contents was $3.14 \mathrm{~mm}$ BL. The feeding incidence (FI) varied significantly among development stages $\left(\chi^{2}=9.8\right.$, d.f. $=2$, $P=0.007)$ and between tidal phases $\left(\chi^{2}=18.2\right.$, d.f. $=1, P$ $<0.001)$. However, there were no significant differences in FI among strata $\left(\chi^{2}=0.21\right.$, d.f. $\left.=2, P=0.898\right)$, nor between stations $\left(\chi^{2}=1.46\right.$, d.f. $\left.=1, P=0.226\right)$. Consequently, larvae collected during the ebb phase at the flexion stage had the greatest FI. 

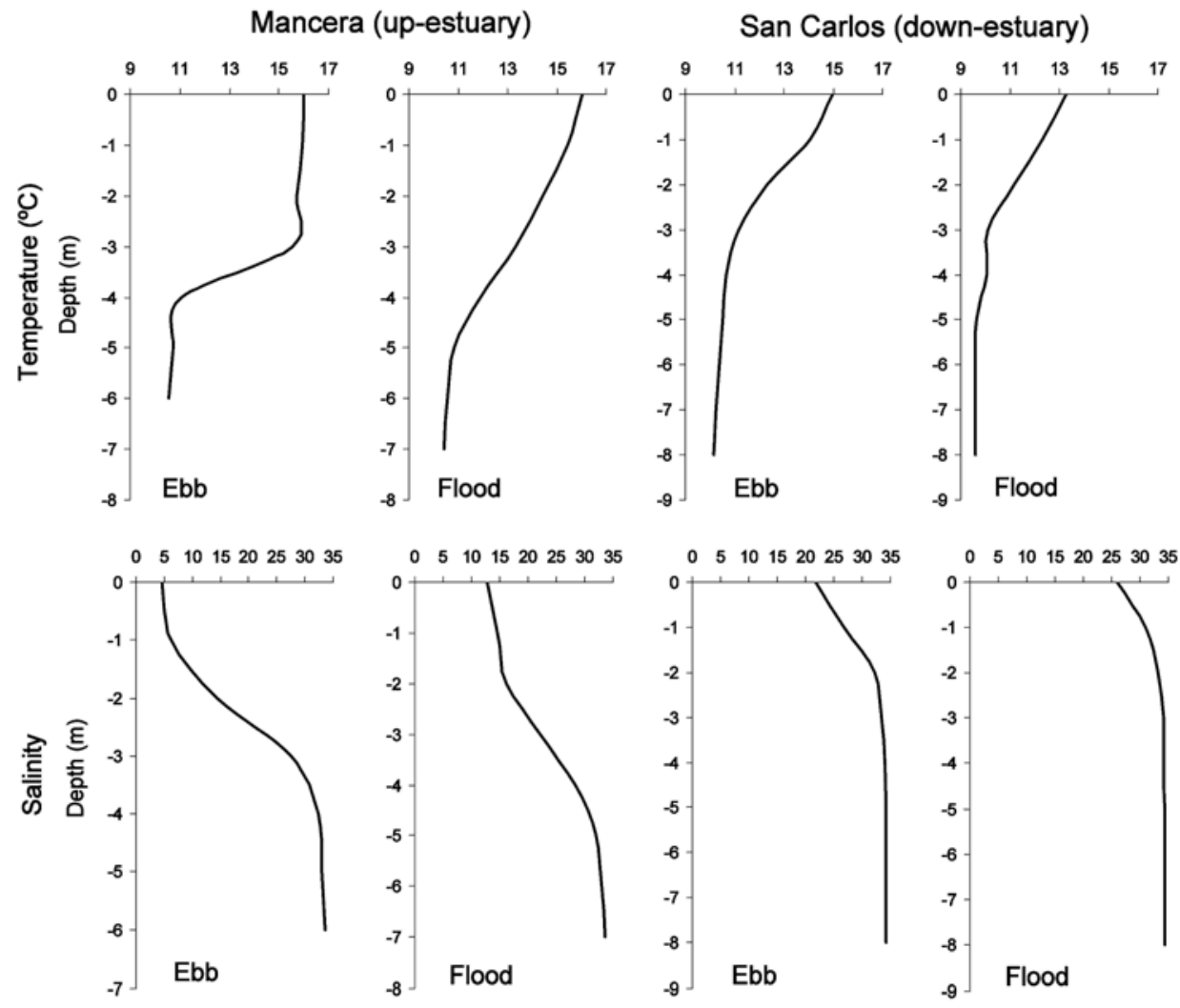

Figure 2. Temperature $\left({ }^{\circ} \mathrm{C}\right)$ and salinity profiles during the ebb and flood tidal phases at Mancera (up-estuary station) and San Carlos (down-estuary station), during 11-12 December 2009 / Perfiles de temperatura $\left({ }^{\circ} \mathrm{C}\right)$ y salinidad durante las fases vaciante y llenante en Mancera (estación estuario-arriba) y San Carlos (estación estuario-abajo) durante el 11-12 de diciembre de 2009
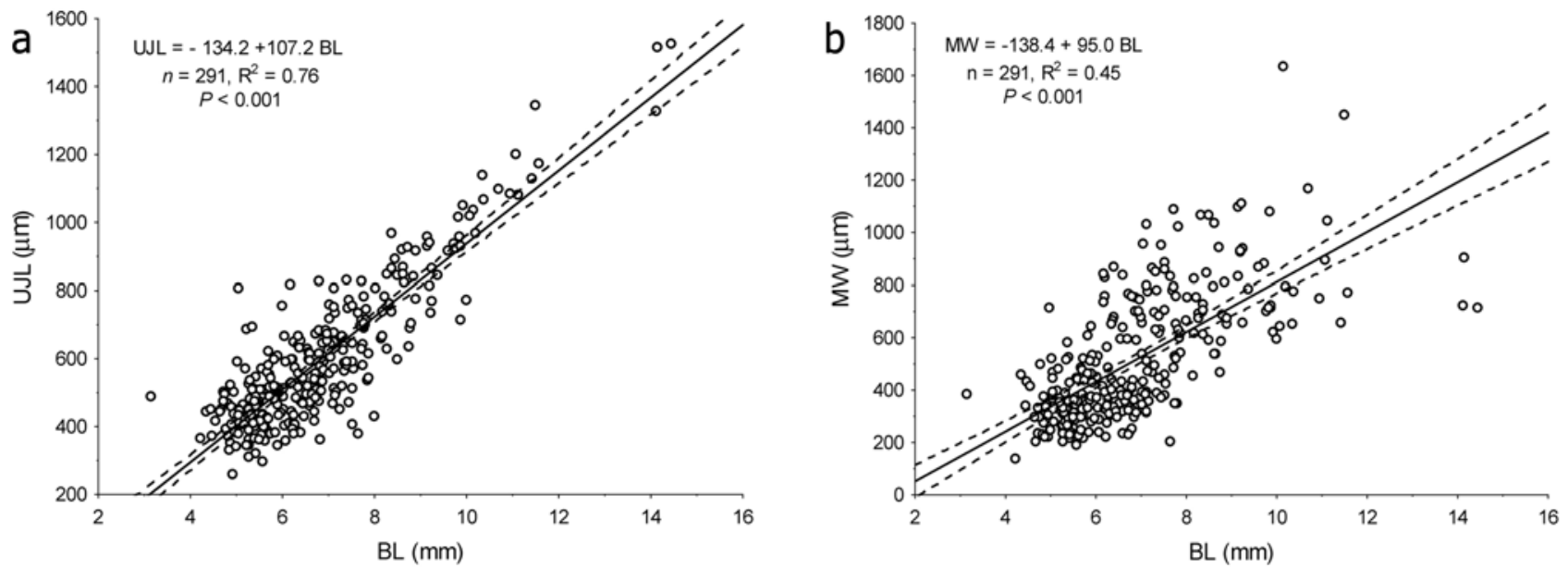

Figure 3. Relationships between body length (BL) and gape size of larval Myxodes viridis. a) upper jaw length (UJL), and b) mouth width (MW). Dashed lines correspond to $\mathbf{9 5 \%}$ confidence intervals / Relaciones entre longitud corporal (BL) y tamaño del hocico de larvas de Myxodes viridis. a) longitud de la mandíbula superior (UJL), y b) ancho del hocico (MW). Las líneas punteadas corresponden a los intervalos de $95 \%$ de confianza 


\section{DIET COMPOSITION AND VARIATION DURING LARVAL DEVELOPMENT}

The diet of $M$. viridis was composed of 31 different prey items, phytoplankton and zooplankton prey (Table 3). A change in the diet composition among developmental stages was evident, varying from omnivory to carnivory. Phytoplanktonic prey items were important in smaller larvae ( 18\%IRI), scarcely found in larvae at the flexion stage $(0.36 \%$ IRI), and totally absent in postflexion larvae (Table 3). Among zooplankton taxa, all life stages of copepods (eggs, nauplii, metanauplii, copepodite, adults) were ingested in large proportions, ranging from 68.86\%IRI (postflexion larvae) to 91.28\%IRI (flexion larvae). Larvae in the flexion stage showed the greatest diversity in diet composition $(S=23)$ among developmental stages.

\section{Prey size, nUmber and volume of Prey}

A total of 387 prey were measured. The prey size (i.e., the maximum prey width) of larval $M$. viridis ranged from 7 $\mu \mathrm{m}$ (a diatom) to $344 \mu \mathrm{m}$ (a balanid nauplius). The number of prey ranged from 0 to $49(2.73 \pm 4.97$ prey items, excluding zeros) and exhibited neither a significant relationship nor a correlation with larval growth (Fig. 4, $r^{2}$ $=0.007, \mathrm{~F}_{1,140}=0.97, P=0.325$; Spearman $\mathrm{r}=0.03, P>$ 0.05 ). Instead, the total volume per gut (TVPG) was positively correlated with the larval size (Spearman $r=$ $0.36, P<0.05)$, and it was weakly explained $\left(r^{2}=0.083\right)$ by the linear model: TVPG $=-0.0052+0.0017 \mathrm{BL}\left(\mathrm{F}_{1,140}=12.62\right.$, $P<0.01$ ) (Fig. 4). There was a weak but significant positive correlation between the prey size and UJL (Spearman $\mathrm{r}=$ $0.56, P<0.05$ ). A linear regression model (MPW $=1.14+$ $\left.0.18 \mathrm{UJL}, \mathrm{F}_{1,385}=120.46, P<0.001\right)$ explained only $24 \%$ of the variability of MPW (Fig. 5).

Table 3. Composition and variation in prey items of larval Myxodes viridis from the Corral Bay estuary, Chile / Composición y variación en los ítems presa de larvas de Myxodes viridis del estuario de la Bahía Corral, Chile

\begin{tabular}{|c|c|c|c|c|c|c|c|c|c|c|c|c|}
\hline \multirow{2}{*}{ Prey items } & \multicolumn{4}{|c|}{ Preflexion larvae } & \multicolumn{4}{|c|}{ Flexion larvae } & \multicolumn{4}{|c|}{ Postflexion larvae } \\
\hline & $\% \mathrm{~N}$ & $\% \mathrm{~F}$ & $\% \mathrm{~V}$ & $\%$ IRI & $\% \mathrm{~N}$ & $\% \mathrm{~F}$ & $\% \mathrm{~V}$ & $\%$ IRI & $\% \mathrm{~N}$ & $\% \mathrm{~F}$ & $\% \mathrm{~V}$ & $\%$ IRI \\
\hline \multicolumn{13}{|l|}{ Phytoplankton } \\
\hline Unidentified microalgae 1 & - & - & - & - & 0.556 & 1.190 & 0.001 & 0.015 & - & - & - & - \\
\hline Unidentified microalgae 2 & - & - & - & - & 1.111 & 1.190 & 0.001 & 0.030 & - & - & - & - \\
\hline Unidentified microalgae 3 & - & - & - & - & 0.556 & 1.190 & 0.001 & 0.015 & - & - & - & - \\
\hline Unidentified diatom & 0.532 & 2.273 & 0.001 & 0.035 & - & - & - & - & - & - & - & - \\
\hline Coscinodiscus sp. & 24.468 & 15.909 & 5.640 & 14.008 & 2.778 & 3.571 & 0.007 & 0.222 & - & - & - & - \\
\hline Surirella sp. & 28.191 & 4.545 & 0.093 & 3.760 & - & - & - & - & - & - & - & - \\
\hline Cyst & 0.532 & 2.273 & 0.280 & 0.054 & - & - & - & - & - & - & - & - \\
\hline Unidentified dinoflagellate & - & - & - & - & 1.111 & 2.381 & 0.038 & 0.061 & - & - & - & - \\
\hline Gonyaulax sp. & - & - & - & - & 0.556 & 1.190 & 0.001 & 0.015 & - & - & - & - \\
\hline \multicolumn{13}{|l|}{ Zooplankton } \\
\hline Tintiniid & 1.596 & 6.818 & 3.810 & 1.078 & 3.333 & 5.952 & 1.806 & 0.684 & - & - & - & - \\
\hline Bivalve larvae & 0.532 & 2.273 & 1.253 & 0.119 & - & - & - & - & - & - & - & - \\
\hline \multicolumn{13}{|l|}{ Copepoda } \\
\hline Copepod eggs & 14.362 & 20.455 & 8.286 & 13.547 & 6.111 & 7.143 & 3.390 & 1.518 & - & - & - & - \\
\hline Nauplii & 10.638 & 31.818 & 9.695 & 18.920 & 30.556 & 45.238 & 16.074 & 47.196 & 26.316 & 38.462 & 13.575 & 23.920 \\
\hline Metanauplii (Rhincalanus nasutus) & - & - & - & - & 1.111 & 2.381 & 0.223 & 0.071 & - & - & - & - \\
\hline Copepodite & 10.638 & 29.545 & 32.168 & 36.986 & 18.333 & 29.762 & 22.882 & 27.445 & 42.105 & 46.154 & 20.360 & 44.948 \\
\hline Calanoid copepodite & - & - & - & - & 0.556 & 1.190 & 2.259 & 0.075 & - & - & - & - \\
\hline Copepodite (Acartia tonsa) & - & - & - & - & 0.556 & 1.190 & 0.378 & 0.025 & - & - & - & - \\
\hline Copepodite (Paracalamus indicus) & - & - & - & - & 0.556 & 1.190 & 0.746 & 0.035 & & & & \\
\hline Copepodite (Rhincalamus nasutus) & - & - & - & - & 0.556 & 1.190 & 0.211 & 0.020 & & & & \\
\hline Copepodite (Oncaea sp.) & - & - & - & - & 0.556 & 1.190 & 2.004 & 0.068 & - & - & - & - \\
\hline Harpacticoid copepodite & 0.532 & 2.273 & 4.068 & 0.306 & - & - & - & - & - & - & - & - \\
\hline Paracalamus indicus & 0.532 & 2.273 & 3.279 & 0.253 & - & - & - & - & - & - & - & - \\
\hline Nauplii remains & - & - & - & - & 3.889 & 8.333 & 2.576 & 1.205 & - & - & - & - \\
\hline Copepodite remains & 1.596 & 4.545 & 1.705 & 0.439 & 12.778 & 19.048 & 17.908 & 13.077 & - & - & - & - \\
\hline Copepod remains & - & - & & & 2.222 & 2.381 & 8.069 & 0.548 & - & - & - & - \\
\hline Invertebrate eggs & 1.064 & 4.545 & 0.512 & 0.209 & 4.444 & 9.524 & 0.989 & 1.158 & 15.789 & 23.077 & 20.880 & 13.193 \\
\hline Balanid larvae (Balanus sp.) & - & - & - & - & - & - & - & - & - & - & - & - \\
\hline Cypris larvae & - & - & - & - & 0.556 & 1.190 & 1.169 & 0.046 & 10.526 & 15.385 & 41.239 & 12.416 \\
\hline Polychaeta larvae & 1.064 & 4.545 & 1.286 & 0.312 & - & - & - & - & - & - & - & - \\
\hline Crustacean remains & 0.532 & 2.273 & 1.515 & 0.136 & 1.111 & 2.381 & 1.639 & 0.146 & - & - & - & - \\
\hline Chitinous remains & 3.191 & 11.364 & 26.410 & 9.837 & 6.111 & 11.905 & 17.629 & 6.323 & 5.263 & 38.462 & 3.946 & 5.522 \\
\hline
\end{tabular}



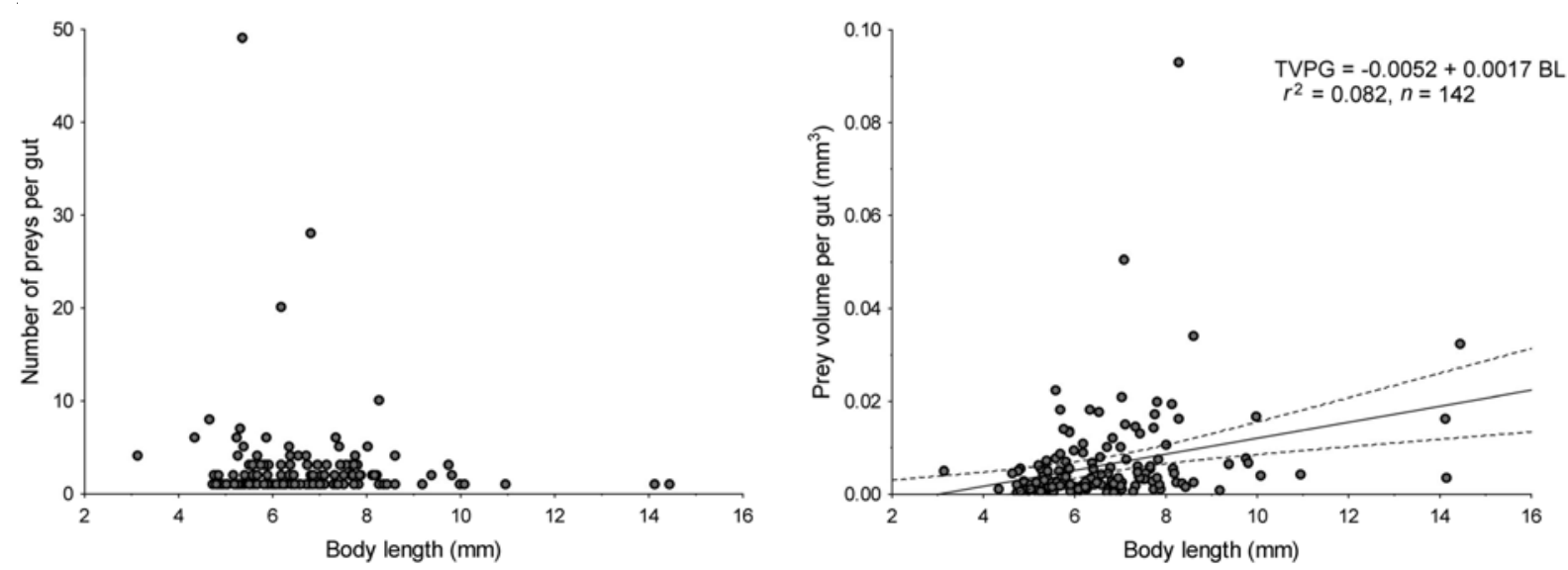

Figure 4. Relationships between number of preys per gut, prey volume per gut and body length of larval Myxodes viridis. Dashed lines correspond to $\mathbf{9 5 \%}$ confidence intervals / Relaciones entre el número de presas por estómago, volumen de presas por estómago y longitud corporal de larvas de Myxodes viridis. Las líneas punteadas corresponden a los intervalos de $95 \%$ de confianza

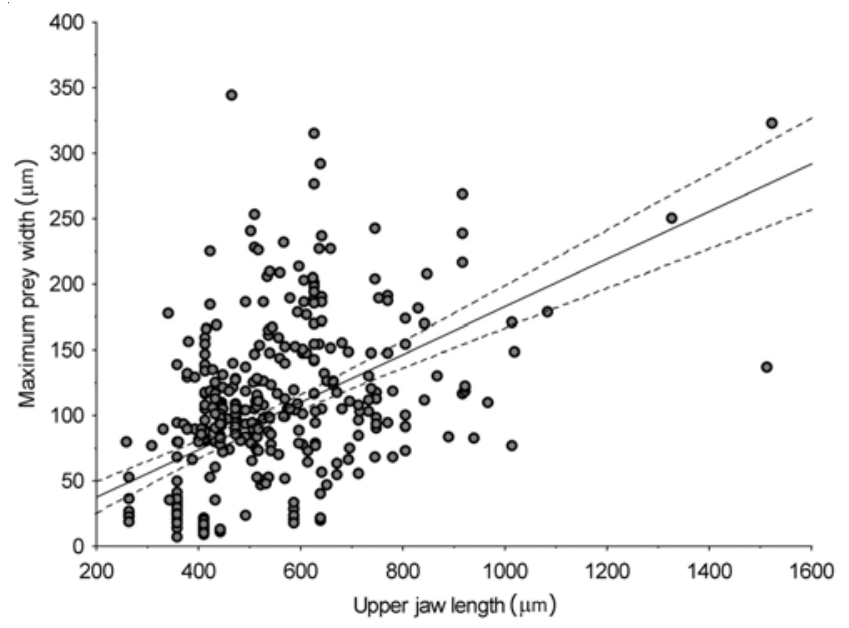

Figure 5. Relationships between the gape size (upper jaw length) and prey size (maximum prey width) of larval Myxodes viridis captured at the Corral Bay estuary during the austral spring, 2009 / Relaciones entre el tamaño del hocico (longitud de la mandíbula superior) y el tamaño de la presa (ancho máximo de la presa) de larvas de Myxodes viridis capturadas en el estuario de la Bahía Corral durante la primavera austral de 2009

\section{FEEDING SUCCESS, DIET COMPOSITION AND WATER COLUMN} STRUCTURE

The larval feeding success indicators (PIPG, PLPG and TPVG) did not vary among strata for each developmental stage of larvae (Table 4, Fig. 6). Nevertheless, there was an evident reduction in the number of prey items and an increase in the volume and size of prey throughout the development of larval Myxodes viridis.

The multivariate analyses indicate that preflexion larvae of $M$. viridis differed in the composition of prey among strata (showed by the NMDS), but in the flexion and postflexion stages, differences among strata were scarce or null (Fig. 7). ANOSIM detected significant differences (global $\mathrm{R}=0.084, P=0.014$ ) in the diet of preflexion larvae from surface and deep strata $(\mathrm{R}=0.096, P=0.016)$ and between larvae from the pycnocline and deep strata $(\mathrm{R}=$ $0.128, P=0.041$ ). There were no differences in the diets of preflexion larvae collected at the surface and at the pycnocline ( $\mathrm{R}=-0.022, P=0.588$ ). SIMPER analyses indicate that dissimilarities in the diets of larvae collected between surface and deep strata were caused mostly by copepodites (19.50\% of contribution), nauplii (17.96\%), and copepod eggs (14.32\%). Dissimilarities in the feeding habits of larvae collected in the pycnocline and deep strata were due to Coscinodiscus sp. (21.62\%), copepodites (18.32\%) and nauplii (17.47\%) prey items. In 
Table 4. Comparison of indices of feeding success among depth strata (surface, pycnocline, deep) for larval Myxodes viridis at different developmental stages. PIPG = number of prey items per gut, PLPG = average prey length per gut, and TPVG = total prey volume per gut. $\mathbf{H}=$ Kruskal-Wallis ANOVA test / Comparación de los índices de éxito alimentario entre estratos de profundidad (superficie, picnoclina, profundo) para larvas de Myxodes viridis en diferentes estados de desarrollo. PIPG = número de ítems presa por estómago, PLPG = longitud promedio de presa por estómago, y TPVG = volumen total de presas por estómago. $\mathrm{H}=$ prueba ANOVA de Kruskal-Wallis

\begin{tabular}{|c|c|c|c|c|c|c|}
\hline & \multicolumn{2}{|c|}{ Preflexion } & \multicolumn{2}{|c|}{ Flexion } & \multicolumn{2}{|c|}{ Postflexion } \\
\hline & $\mathrm{H}$ & $P$ & $\mathrm{H}$ & $P$ & $\mathrm{H}$ & $P$ \\
\hline PIPG & 0.27 & 0.874 & 0.93 & 0.628 & 1.95 & 0.376 \\
\hline PLPG & 3.51 & 0.173 & 0.86 & 0.650 & 3.63 & 0.163 \\
\hline TPVG & 3.92 & 0.141 & 0.61 & 0.736 & 0.81 & 0.665 \\
\hline
\end{tabular}
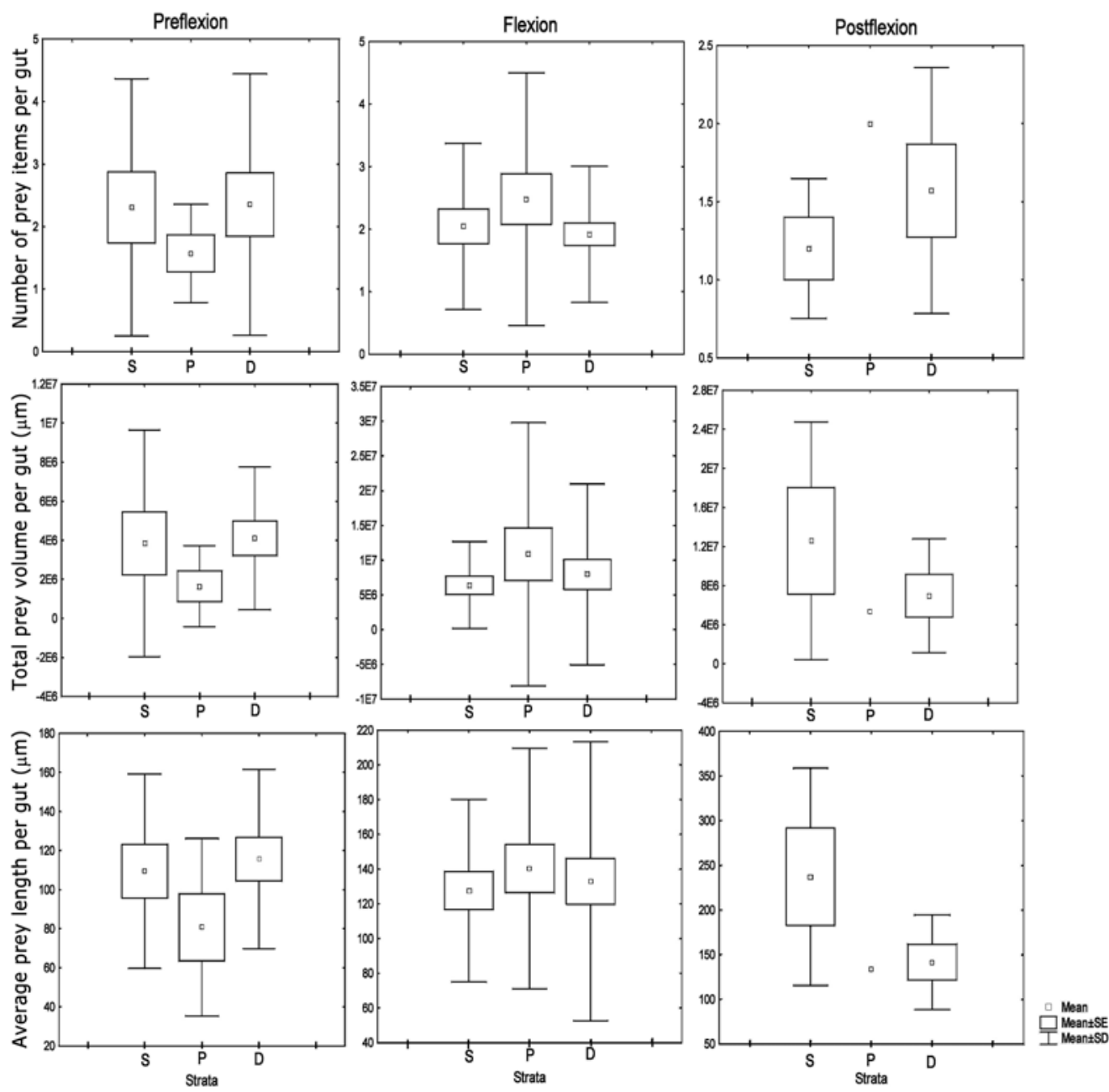

Figure 6. Feeding success of larval Myxodes viridis at different developmental stages, measured as the total number of prey items per gut, total volume of prey items per gut and average prey size per gut. $S=$ surface stratum, $P=$ pycnocline stratum, $D=$ deep stratum. Larvae were collected at the down-estuary station (San Carlos) / Éxito alimentario de larvas de Myxodes viridis a diferentes estados de desarrollo, medidas como el número de ítems presa por estómago, volumen total de presas por estómago y tamaño promedio de presas por estómago. $S=$ estrato superficial, $P=$ estrato de la picnoclina, $D$ = estrato profundo. Las larvas fueron recolectadas en la estación estuario-abajo (San Carlos) 


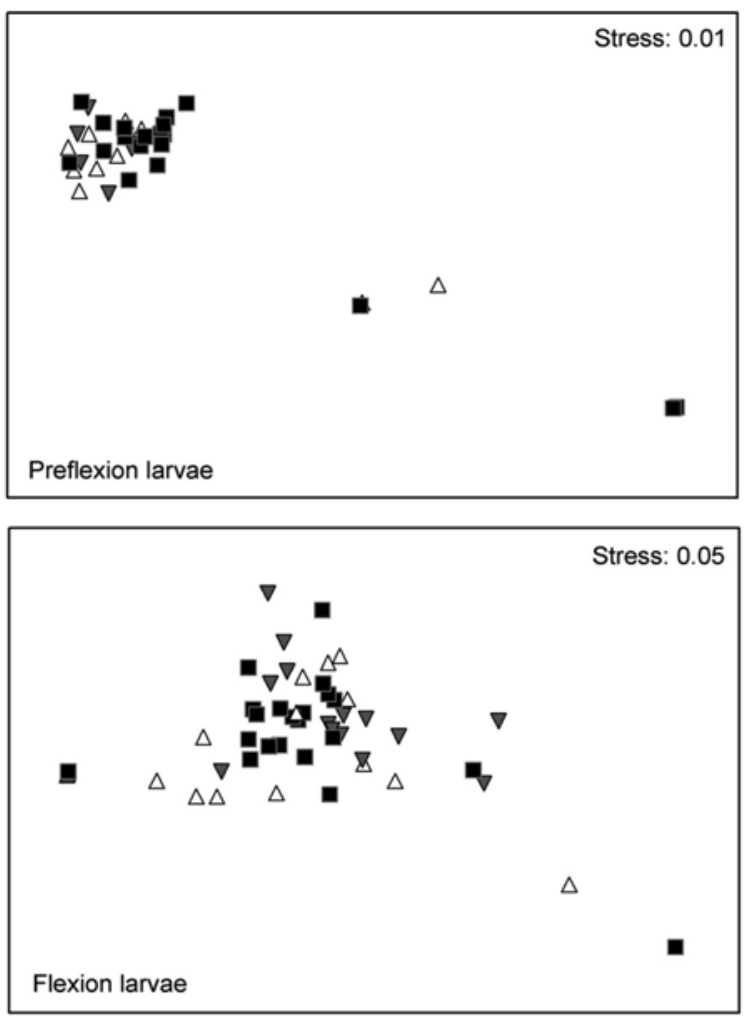

larval $M$. viridis at the flexion stage, differences in diet were also detected (global $\mathrm{R}=0.111, P=0.001$ ). Similar to the preflexion larvae, differences in diet were observed between flexion larvae from surface and deep strata $(\mathrm{R}=$ $0.135, P=0.002$ ) and between larvae from the pycnocline and deep strata $(\mathrm{R}=0.138, P=0.001)$. Dissimilarities were caused by nauplii (25.94\%), copepodites $(22.79 \%)$ and copepod eggs $(11.10 \%)$ in the case of larvae from the surface and deep strata, and by nauplii (25.86\%), copepodites (21.73\%) and copepodite remains (9.97\%) for larvae collected in the pycnocline and deep strata. In the case of postflexion larvae, no significant differences were detected in diet among strata (global $\mathrm{R}=-0.120, P=$ 0.667).

\section{Discussion}

The early life stages of Myxodes viridis (Clinidae) collected from the Corral Bay estuary during the austral spring 2009 were more abundant at the down-estuary station during the ebb phase of the tidal cycle. Larvae change from omnivory to carnivory as they grow, selecting larger prey (from dinoflagellates to large copepods) as the mandible length increases. Foraging

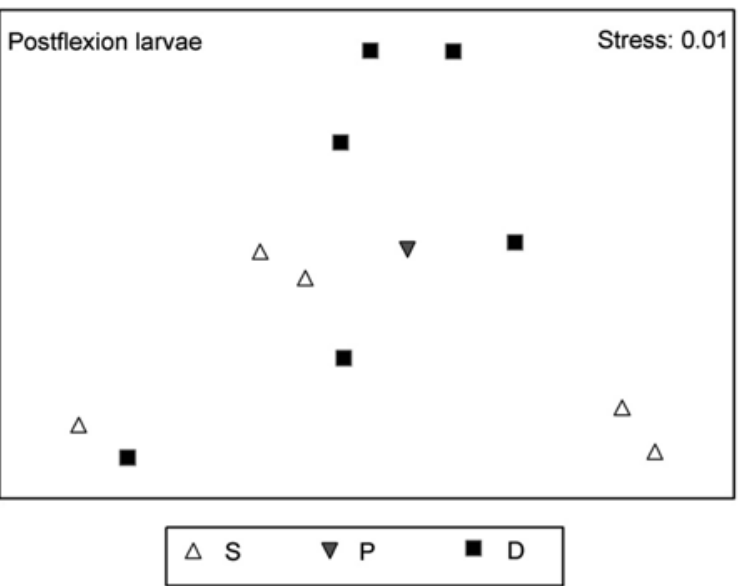

Figure 7. Nonmetric multidimensional scaling (NMDS) of prey items ingested by larval Myxodes viridis at different vertical strata. $S=$ surface stratum, $P=$ pycnocline stratum, $D=$ deep stratum. Larvae were collected at the down-estuary station (San Carlos) / Escalamiento No métrico multidimensional (NMDS) de los ítems presa ingeridos por larvas de Myxodes viridis a diferentes estratos verticales. $\mathrm{S}=$ estrato superficial, $\mathrm{P}=$ estrato de la picnoclina, $\mathrm{D}=$ estrato profundo. Las larvas fueron recolectadas en la estación estuario-abajo (San Carlos)

occurred mostly during the ebb phase of the tidal cycle. Although the feeding success was similar for each developmental stage at all depths, the data suggest that predation in the first 3-4 $\mathrm{m}$ (surface and pycnocline) was on different prey items than in deeper waters, at least for the preflexion and flexion stages. Therefore, the pycnocline may affect the composition of the diet of small, larval M. viridis but not the size or number of prey ingested by larvae in the estuary.

Most larval M. viridis were captured at San Carlos (down-estuary) during the ebb phase. The greater larval fish abundance associated with ebbing conditions may be a tactic of the species to increase advection down the estuary and to the nearby shelf waters. According to Whitfield (1989), pulsed hatching on the ebb tide would enhance the movement of larvae into the ocean for the marine phase that is required by some species for further development. Some coastal fish larvae from Australian (Favonigobius lateralis, Pseudogobius olorum, Neira \& Potter 1992) and South African estuaries (Omobranchus woodi, Psammogobius knysnaensis and Syngnathus acus, Strydom \& Wooldridge 2005) are also flushed out of the estuaries on ebb tides. Some species return to the estuary by sinking deep in the water column during the later stages 
of larval development, whereas others maintain a surface position and exploit gyres or wind-driven countercurrents for retention on the inner shelf near the parent estuary (Epifanio 1988).

The increase in feeding during ebbing conditions has been observed in labrisomid species from the Galapagos, Dialommus fuscus (Nieder 2001). This species forages in the wet sections of the intertidal habitat during low tide. Other blennies show an opposite trend, with greater feeding activity during the rising tide than during the ebbing tide (Faria \& Almada 2008). Other species, such as the juvenile Dicentrarchus labrax, colonize intertidal marsh creeks during the flood phase, forage on resident amphipods, and return to coastal waters during the ebb phase (Laffaille et al. 2001). The asymmetry in food ingestion may reflect a trade-off between maximization of feeding time and the ability to reach the low-tide shelters in time, to avoid the risk of stranding in unsuitable environments.

The change from omnivory to carnivory has been observed in fish larvae from several coastal environments (cod Gadus morhua, Kane 1984; sand lance Ammodytes americanus, Monteleone \& Peterson 1986; anchovy Engraulis ringens, sardine Strangomera bentincki, Llanos-Rivera et al. 2004), and it has been consider an opportunistic behavior. While some species show omnivory throughout the larval stage in estuarine systems, some other fish larvae are exclusively carnivorous (herring Clupea harengus, Fox et al. 1999; lightfish Maurolicus parvipinnis, Landaeta et al. 2011). Juveniles and adults of Myxodes viridis are carnivorous, predating mostly on crabs, amphipods and harpacticoid copepods (Stepien 1990, Muñoz \& Ojeda 1997). Additionally, differences in the composition of prey and the prey size among developmental stages may indicate that intraspecific competition is reduced or absent. Generally, small larvae are poor predators relative to the larger larvae due to their poorer vision, cognitive capacity and swimming activity; thus, they are more vulnerable to variations in food availability (Sassa \& Tsukamoto 2012).

At each developmental stage, larvae were similarly successful at ingesting their prey at different depths of the estuary. Although several studies have highlighted the role of clines in the aggregation of zooplankters and their food, creating biological hotspots (Raby et al. 1994, Grønkjær \& Wieland 1997, Woodson \& McManus 2007, Tapia et al. 2010, Woodson et al. 2012), a strong halocline (i.e., pycnocline) occurred throughout the study at both stations, and this oceanographic feature did not affect the feeding success of fish larvae. Pycnoclines may provide optimal conditions for phytoplankton growth and can be regions of enhanced phytoplankton biomass as a result of both passive and active organism responses (McManus \& Woodson 2012). Differences in the prey composition of $M$. viridis larvae were identified by the multivariate analyses; these analyses suggested different prey fields in the surface/halocline and deep strata of the estuary that can be utilized by fish larvae in a successful way, irrespective of the physical conditions of the water column (i.e., heavy turbulence in the surface and deep strata and greater stability in the pycnocline).

The study area, the Corral Bay estuary, is utilized as spawning and early nursery grounds by a series of marine and estuarine fishes (sardine Strangomera bentincki, silverside Odontesthes regia, Vargas et al. 2003) and crustaceans (crabs Cancer edwardsii and C. coronatus, Pardo et al. 2010, 2011, 2012). In this estuary, crab settlement is related to the advection of warm waters toward the coast and/or coastal upwelling, but it is species-specific (Pardo et al. 2012); microtides may affect larval fish composition, and in our case, the feeding incidence of fish larvae. The absence and/or reduced abundance of larval $M$. viridis in the up-estuary station may be regulated by or associated with salinity tolerance.

Studies of larval ecology in estuaries from the southeastern Pacific Ocean are scarce, and this is the first investigation to focus on the trophic preferences of a larval clinid in a microtidal estuary. It is important to continue investigating the role of estuaries as nursery areas for marine, non-resident fish species, especially in terms of growth and survival.

In conclusion, larvae of the clinid Myxodes viridis did not display estuarine dependence in their diet in Corral Bay estuary. They were collected during the austral spring, mainly during the ebb phase of the tidal cycle, a period when they increase their capability to ingest prey items. During the preflexion and flexion stages, i.e., when swimming capabilities are reduced, they predate on small phyto- and zooplankton, and as the larvae grow, they become strictly carnivorous.

During the study period, the microtidal estuary displayed a prominent halocline at 2-3 m depth; however, this oceanographic feature did not affect the feeding success of larval $M$. viridis. If the pycnocline concentrates food items, fish larvae were unable to increase their prey ingestion; alternatively, a similar feeding success may indicate that the larval clinids forage equally in the mixed and deep layers as well as the pycnocline. 


\section{ACKNOWLedgments}

Authors want to thank J.L. Ochoa, M.E. Muñoz, and F. Salas-Berrios for their constant support during the development of this investigation. This research was partially funded by project DID S-2008-58 (Universidad Austral de Chile) adjudicated to Dr. Julio Lamilla and MFL; and FONDECYT 11090020 adjudicated to MFL. During the writing of the ms, CAB was partially funded by a CONICYT doctoral scholarship.

\section{LITERATURE CITED}

Able KW. 2005. A re-examination of fish estuarine dependence: evidence for connectivity between estuarine and ocean habitats. Estuarine, Coastal and Shelf Science 64: 5-17.

Beck MW, KL Heck Jr, KW Able, DL Childers, DB Eggleston, BM Gillanders, BS Halpern, CG Hays, K Hoshino, TL Minello, TJ Orth, PF Sheridan \& PM Weinstein. 2003. The role of near shore ecosystems as fish and shellfish nurseries. Issues in Ecology, Ecological Society of America 11: 1-12.

Bustos CA, MF Landaeta \& F Balbontín. 2008. Spawning and early nursery areas of anchoveta Engraulis ringens Jenyns, 1842 in fjords of southern Chile. Revista de Biología Marina y Oceanografía 43: 381-389.

Cass-Calay SL. 2003. The feeding ecology of larval Pacific hake (Merluccius productus) in the California Current region: an updated approach using a combined OPC/MOCNESS to estimate prey biovolume. Fisheries Oceanography 12: 34-48.

Cortés E. 1997. A critical review of methods of studying fish feeding based on analysis of stomach contents: application to elasmobranch fishes. Canadian Journal of Fisheries and Aquatic Sciences 54: 726-738.

Davila PM, D Figueroa \& E Muller. 2002. Freshwater input into the coastal ocean and its relation with the salinity distribution off austral Chile $\left(35-55^{\circ} \mathrm{S}\right)$. Continental Shelf Research 22: 521-534.

Epifanio CE. 1988. Transport of invertebrate larvae between estuaries and the continental shelf. American Fisheries Society Symposium 3: 104-114.

Faria C \& VC Almada. 2008. Temporal asymmetries in the feeding patterns along the tidal cycle in two sympatric littoral blennies. Estuarine, Coastal and Shelf Science 79: 566-568.

Fox CJ, R Harrop \& A Wimpenny. 1999. Feeding ecology of herring (Clupea harengus) larvae in the turbid Blackwater Estuary. Marine Biology 134: 353-365.

Gibrán FZ, FB Santos, HF dos Santos \& J Sabino. 2004. Courtship behavior and spawning of the hairy blenny Labrisomus nuchipinnis (Labrisomidae) in southeastern Brazil. Neotropical Ichthyology 2: 163-166.
Grønkjær P \& K Wieland. 1997. Ontogenetic and environmental effects on vertical distribution of cod larvae in the Bornholm Basin, Baltic Sea. Marine Ecology Progress Series 154: 91-105.

Islam MS, M Hibino \& M Tanaka. 2006. Distribution and diets of larval and juvenile fishes: influence of salinity gradient and turbidity maximum in a temperate estuary in upper Ariake Bay, Japan. Estuarine, Coastal and Shelf Science 68: 62-74.

Kane J. 1984. The feeding habits of co-occurring cod and haddock larvae from Georges Bank. Marine Ecology Progress Series 16: 9-20.

Laffaille P, JC Lefeuvre, MT Schricke \& E Feunteun. 2001. Feeding ecology of 0-group sea bass, Dicentrarchus labrax, in salt marshes of Mont Saint Michel Bay (France). Estuaries 24: 116-125.

Landaeta MF, N Suárez-Donoso, CA Bustos \& F Balbontín. 2011. Feeding habits of larval Maurolicus parvipinnis (Pisces: Sternoptychidae) in Patagonian fjords. Journal of Plankton Research 33: 1813-1824.

Landaeta MF, G López, N Suárez-Donoso, CA Bustos \& F Balbontín. 2012. Larval fish distribution, growth and feeding in Patagonian fjords: potential effects of freshwater discharge. Environmental Biology of Fishes 93: 73-87.

Llanos-Rivera A, G Herrera \& P Bernal. 2004. Food size selectivity and diet overlap in larvae of Clupeiform species from central Chile. Cahiers de Biologie Marine 45: 1-8.

McManus MA \& CB Woodson. 2012. Plankton distribution and ocean dispersal. Journal of Experimental Biology 215: 1008-1016.

Monteleone DM \& WT Peterson. 1986. Feeding ecology of American sand lance Ammodytes americanus larvae from Long Island Sound. Marine Ecology Progress Series 30: 133-143.

Muñoz AA \& FP Ojeda. 1997. Feeding guild structure of a rocky intertidal fish assemblage in central Chile. Environmental Biology of Fishes 49: 471-479.

Neira FJ \& IC Potter. 1992. Movement of larval fishes through the entrance channel of a seasonally open estuary in Western Australia. Estuarine, Coastal and Shelf Science 35: 213-224.

Neira FJ, AG Miskiewicz \& T Trnski. 1998. Larvae of temperate Australian fishes. Laboratory guide for larval fish identification, 474 pp. University of Western Australia Press, Nedlands.

Nieder J. 2001. Amphibious behaviour and feeding ecology of the four-eyed blenny (Dialommus fuscus, Labrisomidae) in the intertidal zone of the island of Santa Cruz (Galapagos, Ecuador). Journal of Fish Biology 58: 755-767.

North EW \& ED Houde. 2001. Retention of white perch and striped bass larvae: biological-physical interactions in Chesapeake Bay Estuarine Turbidity Maximum. Estuaries 24: 756-769. 
Pardo LM, CS Cardyn, P Mora \& RA Wahle. 2010. A new passive collector to assess settlement rates, substrate selection and predation pressure in decapod crustacean larvae. Journal of Experimental Marine Biology and Ecology 393: 100-105.

Pardo LM, K González, JP Fuentes, K Paschke \& OR Chaparro. 2011. Survival and behavioral responses of juvenile crabs of Cancer edwardsii to severe hyposalinity events triggered by increased runoff at an estuarine nursery ground. Journal of Experimental Marine Biology and Ecology 404: 33-39.

Pardo LM, P Mora-Vásquez \& J Garcés-Vargas. 2012. Daily settlement of Cancer crab megalopae in a microtidally estuary. Latin American Journal of Aquatic Research 40: 142-152.

Pino M, GME Perillo \& P Santamaría. 1994. Residual fluxes in a cross-section of the Valdivia river Estuary, Chile. Estuarine, Coastal and Shelf Science 38: 491-505.

Quijada PA \& CW Caceres. 2000. Abundance, trophic composition and spatial distribution of the intertidal fish assemblage of south-central Chile. Revista Chilena de Historia Natural 73: 739-747.

Raby D, Y Lagadeuc, JJ Dodson \& M Mingelbier. 1994. Relationship between feeding and vertical distribution of bivalve larvae in stratified and mixed waters. Marine Ecology Progress Series 103: 275-284.

Reiss CS, A Anis, CT Taggart, JF Dower \& B Ruddick. 2002. Relationships among vertically structured in situ measures of turbulence, larval fish abundance and feeding success and copepods on Western Bank, Scotian Shelf. Fisheries Oceanography 11: 156-174.

Sassa C \& K Kawaguchi. 2004. Larval feeding habits of Diaphus garmani and Myctophum asperum (Pisces: Myctophidae) in the transition region of the western North Pacific. Marine Ecology Progress Series 278: 279-290.

Sassa C \& Y Tsukamoto. 2012. Inter-annual comparison of diet and daily ration of larval jack mackerel Trachurus japonicus in the southern East China Sea. Journal of Plankton Research 34: 173-187.
Stephens JS \& VG Springer. 1973. Clinid fishes of Chile and Peru, with description of a new species, Myxodes ornatus, from Chile. Smithsonian Contribution to Zoology 159: 124.

Stepien CA. 1990. Population structure, diets and biogeographic relationships of a rocky intertidal fish assemblage in central Chile: high levels of herbivory in a temperate system. Bulletin of Marine Science 47: 598-612.

Stepien CA. 1992. Evolution and biogeography of the Clinidae (Teleostei: Blennioidei). Copeia 1992: 375-392.

Strydom N \& TH Wooldridge. 2005. Diel and tidal variations in larval fish exchange in the mouth region of the Gamtoos Estuary, South Africa. African Journal of Aquatic Science 30: 131-140.

Sun J \& D Liu. 2003. Geometric models for calculating cell biovolume and surface area for phytoplankton. Journal of Plankton Research 25: 1331-1346.

Tapia FJ, C DiBacco, J Jarrett \& J Pineda. 2010. Vertical distribution of barnacle larvae at a fixed nearshore station in southern California: Stage-specific and diel patterns. Estuarine, Coastal and Shelf Science 86: 265-270.

Vargas CA, SE Araneda \& G Valenzuela. 2003. Influence of tidal phase and circulation on larval fish distribution in a partially mixed estuary, Corral Bay, Chile. Journal of Marine Biological Association of the United Kingdom 83: 217-222.

Whitfield AK. 1989. Ichthyoplankton interchange in the mouth region of a southern African estuary. Marine Ecology Progress Series 54: 25-33.

Woodson CB \& BA McManus. 2007. Foraging behavior can influence dispersal of marine organisms. Limnology and Oceanography 52: 2701-2709.

Woodson CB, BA McManus, JA Tyburczy, JA Barth, L Washburn, JE Caselle, MH Carr, DP Malone, PT Raimondi, BA Menge \& SR Palumbi. 2012. Coastal fronts set recruitment and connectivity patterns across multiple taxa. Limnology and Oceanography 57: 582-596.

Zar JH. 1999. Biostatistical analysis, 663 pp. Prentice Hall, Upper Saddle River.

Received 3 July 2012 and accepted 29 January 2013

Associate Editor: Gabriela Muñoz C. 